\title{
Estimation of botanical composition of esophageal extrusa samples using near infrared reflectance spectroscopy
}

\author{
JERRY D. VOLESKY AND SAMUEL W. COLEMAN
}

\begin{abstract}
Authors are assistant professor, University of Nebraska-Lincoln, West Central Research and Extension Center, Rt. 4 , Box 46A, North Platte, Nebr. 69101 ; and research animal scientist, USDA-ARS, Grazinglands Research Laboratory, P.O. Box 1199, El Reno, Okla. 73036. At the time of the research, Volesky was with
\end{abstract}

\begin{abstract}
The objective of this study was to evaluate the potential of near infrared reflectance spectroscopy (NIRS) for estimating botanical composition of esophageal extrusa samples. Spectral data were collected on 361 samples from fistulated sheep and cattle grazing native tallgrass range. Principal components analysis was used to identify a subset of 73 samples with spectral dissimilarity. These samples were microhistologically analyzed to determine botanical composition and were considered 'actual' for regression and calibration purposes. Thirty-six species (12 grasses, 22 forbs, and 2 sedges) were identified in the microhistologically analyzed samples. However, most accounted for less than $5 \%$ of the total diet. Additional pure calibration samples were obtained by feeding individual species to confined fistulated sheep. Initial regression analyses and predictions were made on 13 major species or species groups. Satisfactory prediction equations could only be developed for big bluestem (Andropogon gerardii Vitman) $\left(r^{2}=0.61\right)$, and the total grasses $\left(r^{2}=0.79\right)$ and total forbs $\left(r^{2}=0.79\right)$ groups. Addition of spectra from pure samples into the calibration set was beneficial. In general, valid predictions could not be made for individual species that constituted less than $10 \%$ of the sample and/or had a low frequency of occurrence in the calibration samples. The NIRS method offered acceptable precision and accuracy in the prediction of major botanical components and it would be practical and efficient because it reduces the number of samples that would have to be microhistologically analyzed.
\end{abstract}

Key Words: microhistological analysis, double-sampling, diet sampling

Knowledge of the botanical composition of diets of grazing livestock is important because of its relevance to range or grazing management strategies. This is particularly true in mixed grazing approaches where 2 or more classes of livestock may be used. The microhistological examination of esophageal extrusa or fecal samples has been a useful technique for determining botanical composition of diets of grazing livestock. It involves microscopic

Published with the approval of the director of the Univ. of Nebraska-Lincoln, Institute of Agr. and Natur. Resources, Agr. Res. Div. as Journal Ser. no. 11172

Manuscript accepted 29 Apr. 1995. examination of ground sample material and identification and quantification of disconnected plant fragments (Sparks and Malechek 1968). The procedure, however, can be tedious, timeconsuming, and expensive.

Near infrared reflectance spectroscopy (NIRS) has long been a useful tool for rapidly predicting nutritional characteristics of feedstuffs and forages (Norris et al. 1976). More recently, NIRS technology has been applied to forages for the estimation of plant part (leaf) percentages (Hill et al. 1988) and it has also shown potential for estimating botanical composition of complex mixtures of hay and fresh forage (Coleman et al. 1985, 1990), and grass-legume mixtures (Moore et al. 1990; Shaffer et al. 1990; Pitman et al. 1991; Garcia-Criado et al. 1991).

The objective of this study was to evaluate the potential of NIRS for estimating botanical composition of esophageal extrusa collected from cattle and sheep grazing native tallgrass range.

\section{Materials and Methods}

This research was conducted at the USDA-ARS Grazinglands Research Laboratory near El Reno, Okla. A total of 361 diet samples (191 cattle and 170 sheep) were collected using esophagealfistulated livestock during 1989 and 1990 . These samples were from 1 phase of a study evaluating mixed grazing of cattle and sheep on native tallgrass range. The mixed grazing study had 2 replications of 5 treatment pastures and an ungrazed control. Treatments consisted of varying proportions of cattle and sheep. Major perennial grass species present in the pastures included big bluestem (Andropogon gerardii Vitman), tall dropseed [Sporobolus asper (Michx.) Kunth], prairie dropseed (S. heterolepis Gray), and Scribner's panicum [Dicanthelium oligosanthes (J.A. Schultes) Gould]. Common annual grasses were cheatgrass brome (Bromus tectorum L.) and witchgrass (Panicum capillare L.). Major forb species included western ragweed (Ambrosia psilostachya D.C.), Louisiana sagewort (Artemisia ludoviciana Nutt.), and horseweed [Conyza canadensis (L.) Cronq].

Esophageal-fistulated livestock used included 12 yearling and 2-year old steers and 10 wether lambs. These animals grazed in the treatment pastures at all times along with intact animals. Collections were made in the early morning following an 
overnight fast. Two animals of each livestock class were randomly selected and grazed in a pasture ( $1 \mathrm{ha}$ ) for 30 to 45 minutes. Extrusa was thoroughly mixed in the screened-bottomed collection bag, subsampled, and later freeze-dried. Dried samples were then ground through a 1-mm screen using a cyclone type grinder. Collections were made on 4 dates during the summer grazing period each of the 2 years.

An additional group of 26 pure samples (whole-plant) was also included. These samples were compiled from hand-clipped samples taken from the study pastures and contained only an individual species or group (eg. $100 \%$ big bluestem or $100 \%$ forbs). Ten species or species groups from early (Jun.-Jul.) and late (Aug.-Sep.) season clippings were represented in these samples. Samples were individually fed to esophageal-fistulated sheep held in metabolism crates and the extrusa collected, freeze-dried, and ground as previously described.

Near infrared reflectance spectroscopy evaluations were performed on all samples using a Pacific Scientific ${ }^{1}$ model 6250 scanning reflectance monochromator interfaced to a Digital Equipment Co.' Micro VAX II minicomputer. Each sample mixture was packed into sample cells with a near-infrared transparent quartz cover glass and scanned 64 times. Reflected energy (log I/R) was measured, averaged over 64 scans, and recorded at 2$\mathrm{nm}$ intervals from 1,100 to $2,500 \mathrm{~nm}$.

Two microcomputer-based algorithms, CENTER and SELECT (Infrasoft International, Port Matilda, Penn.), were used to select 73 samples (42 sheep and 31 cattle) which served as reference samples (Shenk and Westerhaus 1991b). CENTER ranks samples in a file according to the $\mathrm{H}$-distance (Mahalanobis distance) from the average spectrum of the file. SELECT eliminates samples with similar spectra. Spectral data were transformed by a first derivative math treatment and principal components were calculated. Selected samples were subjected to microhistological analysis using procedures of Sparks and Malechek (1968) performed by a commercial laboratory. ${ }^{2}$ Percent relative density of discerned fragments for a species was calculated from 3 slides/sample and 20 fields/slide. Microhistologically determined composition was considered 'actual' for calibration purposes. Standard error of calibration (SEC) was calculated to assist in selection of the equation that best fit the data.

Calibration equations were validated with a group of samples $(n=20)$ from the same set. None of the samples used in calibration development were used for validation. Two regression methods, PLS (partial least squares) and MSR (modified stepwise regression) were evaluated both with and without scatter correction (Barnes et al. 1989). Equations were developed using each of the above methods and scatter correction combinations on the remaining 53 samples. Twenty-six pure samples were added and additional equations developed. Predicted values for the validation samples were regressed on actual values for evaluation of equations using standard error of prediction (SEP), bias (mean reference analysis values minus mean NIRS derived values), slope, and a simple coefficient of determination $\left(r^{2}\right)$ as selection criteria. Clark et al. (1995) further define selection criteria statistics.

\footnotetext{
Names are neessary to report factually on available datea; however, the USDA neither guarantees nor warrants the standard of the product, and the use of the name by USDA implies no approval of the product to the exclusion of others that also may be suitable.

${ }^{2}$ Composition Analysis Laboratory, 622 1/2 Duff Drive, Fort Collins, Colo. 80524.
}

\section{Results and Discussion}

Thirty-six species (12 grasses, 22 forbs, and 2 sedges) were identified in the 73 microhistologically analyzed samples. However, many had a low frequency of occurrence or accounted for less than $5 \%$ of the total diet. Initial regression analyses and predictions were made on 13 major species or species groups. Six species or groups (5 forbs and annual grasses) were omitted because of unsatisfactory calibration standard errors and $r^{2}$. Subsequent analyses were performed on 7 components which included 2 grasses and 2 forbs as well as total grass, other forb, and total forb groups. The microhistologically determined composition and frequency of these 7 species or groups are given in Table 1. Total grass and forb groups constituted 73.4 and $26.6 \%$ of the samples, respectively, with big bluestem (59.1\%) being the most abundant single species.

Table 1. Frequency of occurrence, mean, and standard error (SE) percent of each species or group in the microhistologically examined calibration set.

\begin{tabular}{|c|c|c|c|c|c|}
\hline \multirow[b]{2}{*}{ Species } & \multirow[b]{2}{*}{ Frequency } & \multirow[b]{2}{*}{ Mean } & \multirow[b]{2}{*}{$\pm \mathrm{SE}$} & \multicolumn{2}{|c|}{ All Samples ${ }^{1}$} \\
\hline & & & & Mean & \pm SE \\
\hline & \multicolumn{3}{|c|}{$(\%)-(N)-\cdots$} & \multicolumn{2}{|c|}{$-\ldots-(\%)---$} \\
\hline Big bluestem & 72 & 60.0 & 4.1 & 59.1 & 4.1 \\
\hline Dropseeds & 50 & 13.2 & 3.3 & 9.1 & 2.4 \\
\hline Western ragweed & 14 & 14.3 & 14.9 & 2.7 & 1.1 \\
\hline Louisiana sagewort & 17 & 24.4 & 17.7 & 5.7 & 2.1 \\
\hline Other forbs & - & - & - & 2.8 & 0.8 \\
\hline Total grass & - & - & - & 73.4 & 3.6 \\
\hline Total forbs & - & - & - & 26.6 & 3.6 \\
\hline
\end{tabular}

Mean percent \pm SE over all samples in dataset $(N=73)$.

Calibration and validation statistics and regression methods for the 7 components are given in Tables 2 and 3 . Big bluestem, total grasses, and total forbs were the only 3 that had suitable prediction equations based on our selection criteria. Statistics for the other forbs group were marginally acceptable. The remaining 3 components (dropseeds, ragweed, and sagewort) averaged from 0.5 to $3.2 \%$ in the calibration dataset (Table 2). Standard errors of calibration and cross validation were as high or higher than the mean percentage of each. Coefficients of variation for these 3 components were high, ranging between 27 and $48 \%$ in the validation dataset (Table 3).

Plots of laboratory-determined vs predicted proportions of total grasses, total forbs, and big bluestem show the linear relationship for these 3 groups (Fig. 1). Validation dataset slopes were 1.03 for total grasses and total forbs and 0.98 for big bluestem.

The most suitable equations for big bluestem, total grasses, and total forbs were derived from the partial least squares (PLS) regression method. Partial least squares uses all of the spectrum while modified stepwise regression (MSR) uses only selected wavelengths. Shenk and Westerhaus (1991a) found that a modified PLS method had similar or better prediction accuracy than MSR across several chemical constituents and populations. Frank (1987) also reported a similar finding using a Monte Carlo simulation.

Addition of spectra from pure samples into the calibration set was beneficial for all components that had suitable equations. Use of pure samples resulted in an expanded range, but more importantly, provided error-free laboratory samples. It is probable 
Table 2. Calibration statistics and regression methods for each species or group that resulted in the best prediction equations.

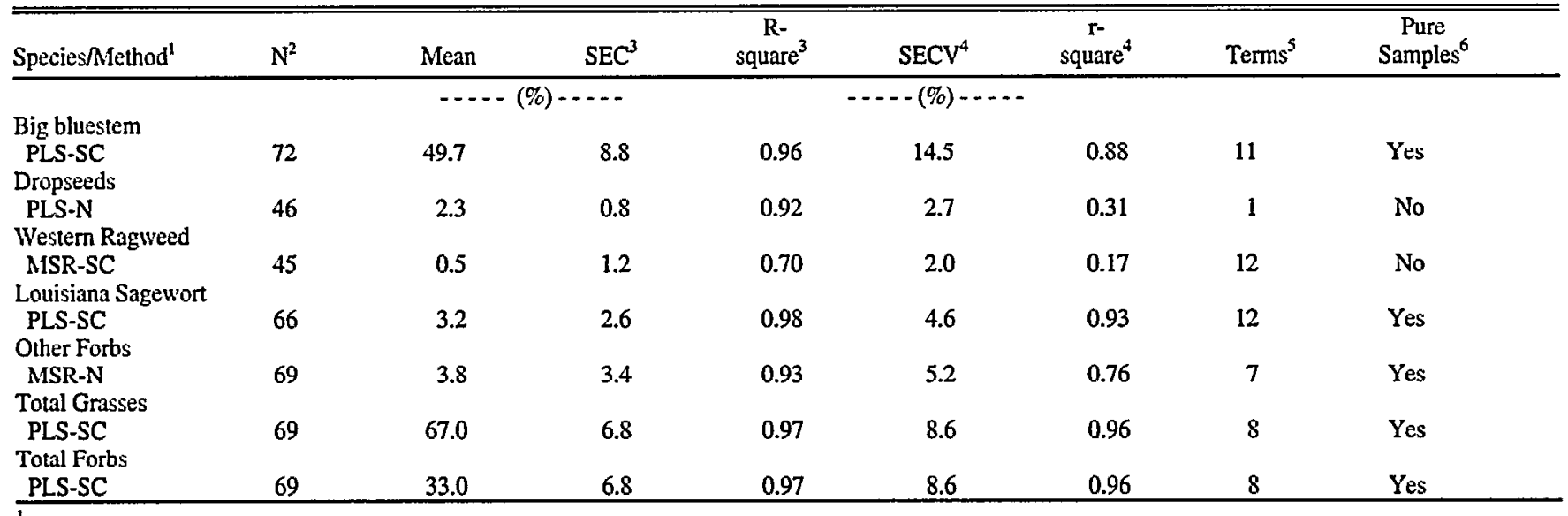

Irethods:

PLS-SC $=$ Partial least squares - scatter correction.

PLS-N = Partial least squares - no scatter correction.

MISR-SC = Modified stepwise regression - scatter correction.

MSR $\cdot N=$ Modified stepwise regression - no scatter correction.

${ }^{2} \mathrm{~N}=$ number of samples with outliers excluded.

${ }^{3} \mathrm{SEC}=$ standard enor of calibration; $\mathrm{R}^{2}$ for calibration.

${ }^{4} \mathrm{SECV}=$ standard error of cross validation; $\mathrm{r}^{2}$ for cross validation.

"Terms refer to number of principal components with PLS method and number of wavelengths with MSR method.

"Indicates whether or not pure samples (100\% of an individual species or group) were used resulting in equation improvement.

that the largest source of error for calibration came from the microhistological procedure to determine botanical composition. Sparks and Malechek (1968) reported an $r^{2}$ of 0.98 for the overall relationship between hand-composited mixtures of 8 species and microhistologically determined proportions. Volesky (unpublished data) microhistologically analyzed hand-composited samples of several species at various proportions and generally found moderately strong relationships $\left(0.72\right.$ to $\left.0.90 \mathrm{r}^{2}\right)$ between the microhistologically determined and actual proportions of major species. However, $r^{2}$ values varied significantly by species and were often poor when amounts of a component were less than $10 \%$.
Another potential source of variation that could limit usefulness of the prediction equations was sampling date. Our samples were collected from June through September and sampling date could have introduced variation in chemical properties and spectral absorption (Coleman et al. 1990). These sampling date changes may vary by individual component and could occur without change in botanical composition. Introducing date as a covariate may reduce some of the variation. Another factor that could alter spectral absorption is salivary contamination of the esophageal extrusa samples. Saliva will generally increase the ash content and may alter amounts of other chemical constituents by varying degrees (Holechek et al. 1982).

Table 3. Validation statistics and regression methods for each species or group that resulted in best prediction equations ( $N=20)$.

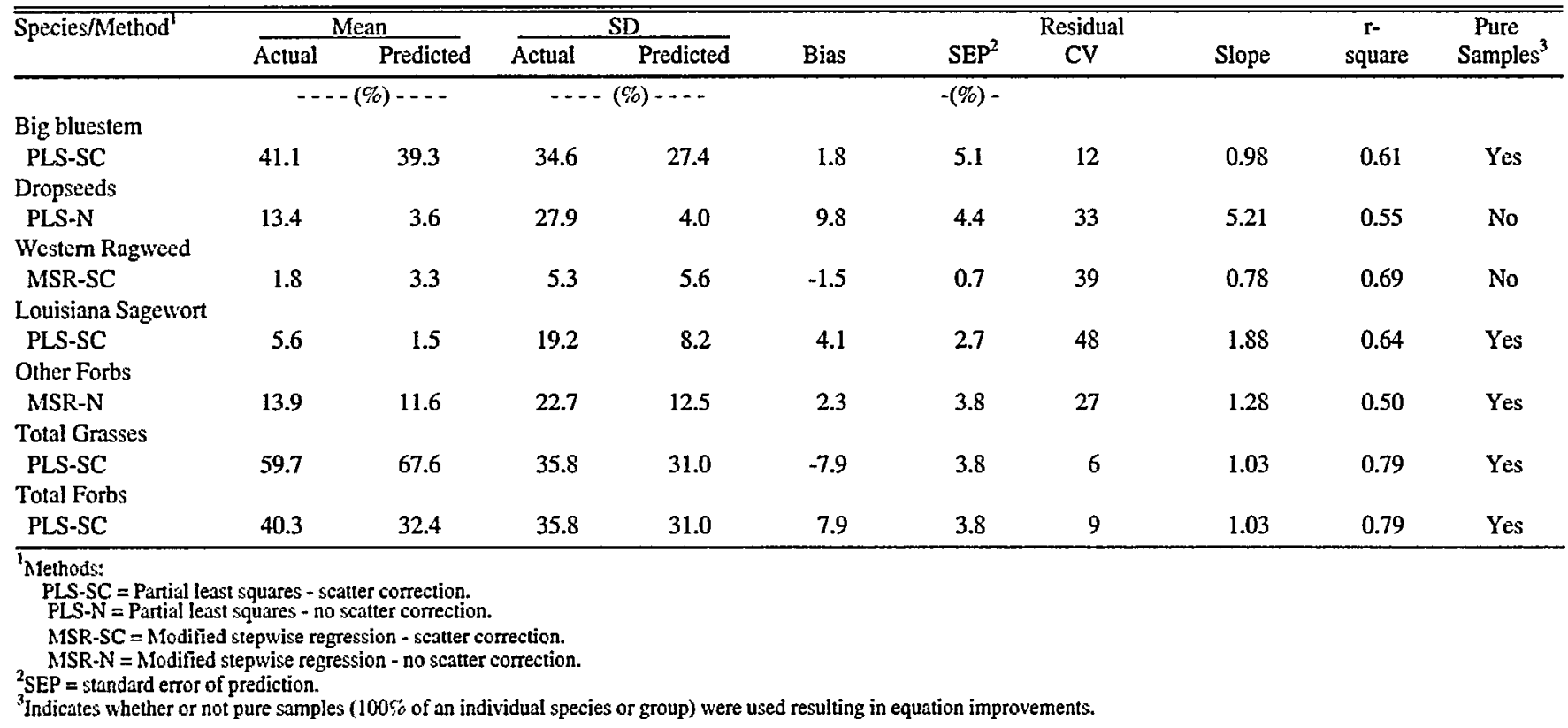



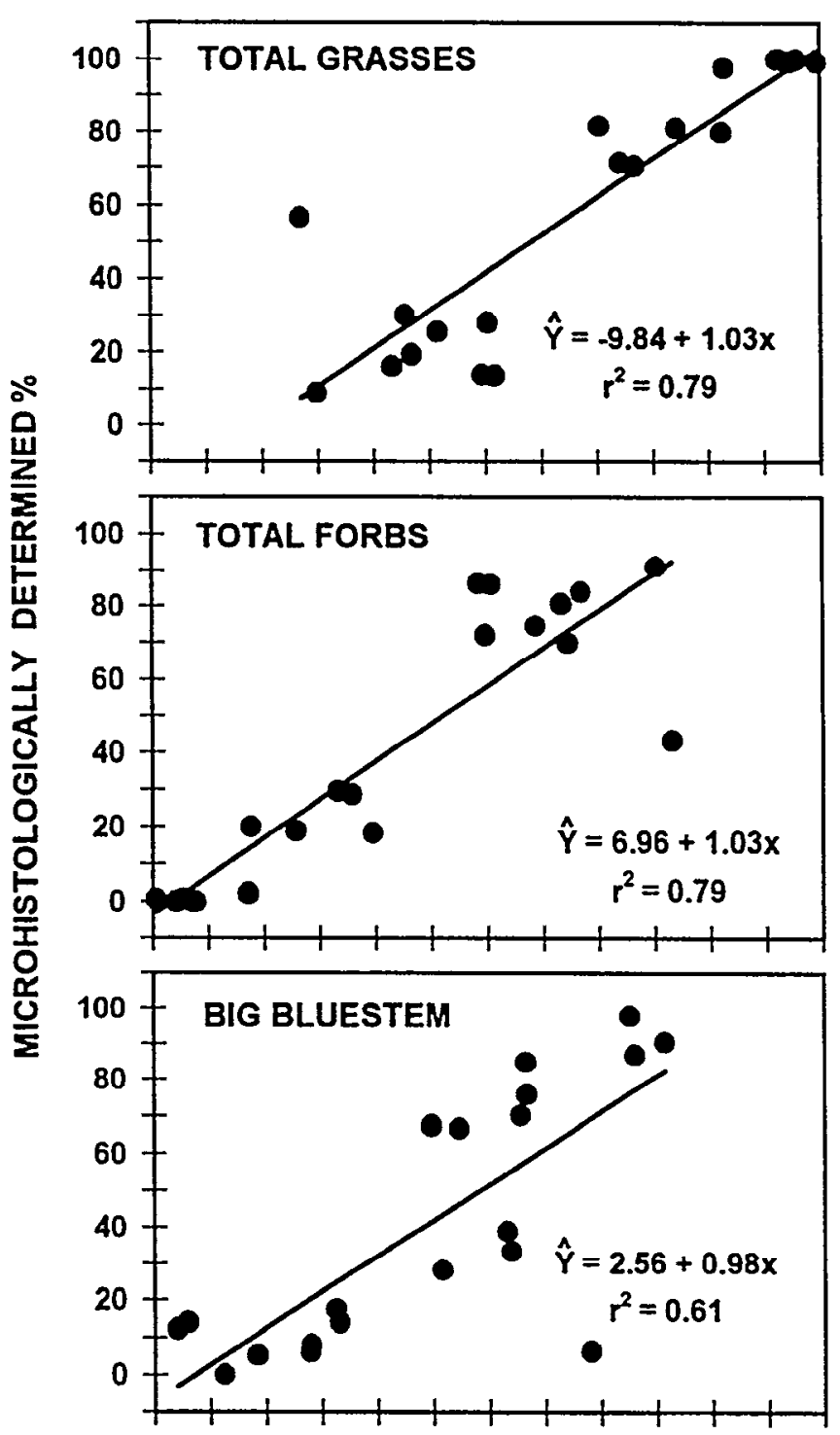

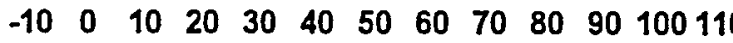

\section{NIRS PREDICTED \%}

Fig. 1. Relationship of NIRS-predicted percentages of total grasses, total forbs, and big bluestem to microhistologically determined composition for the validation dataset.

\section{Conclusions}

In general, valid predictions could not be made for individual species or components that averaged less than $10 \%$ of the sample and/or had a low frequency of occurrence in the calibration samples. There are more sources of error in estimating the botanical composition of complex esophageal extrusa samples than when estimating standard chemical composition. Consequently, NIRS was not capable of quantifying botanical composition of minor constituents. The NIRS method did, however, offer acceptable precision and accuracy when predicting major botanical components. Its use in this type of double-sampling application in a closed population would be practical and efficient because of the substantial reduction in the number of samples that would have to be microhistologically analyzed.

\section{Literature Cited}

Barnes, R.J., M.S. Dhanoa, and S.J. Lister. 1989. Standard normal variate transformation and de-trending of near-infrared diffuse reflectance spectra. Appl. Spectrosc. 43:772-777.

Clark, D.H., D.A. Johnson, K.D. Kephart, and N.A. Jackson. 1995. Near infrared reflectance spectroscopy estimation of ${ }^{13} \mathrm{C}$ discrimination in forages. J. Range Manage. 48:132-136.

Coleman, S.W., F.E. Barton, and R.D. Meyer. 1985. The use of nearinfrared reflectance spectroscopy to predict species composition of forage mixtures. Crop Sci. 25:834-837.

Coleman, S.W., S. Christiansen, and J.S. Shenk. 1990. Prediction of botanical composition using NIRS calibration developed from botanically pure samples. Crop Sci. 30:202-207.

Frank, I.E. 1987. Intermediate least squares regression method. Chemnometrics Intelligent Lab. Syst. 1:233-242.

Garcia-Criado, B., A. Garcia-Ciudad, and M.E. Perez-Corona. 1991. Prediction of botanical composition in grassland herbage samples by near-infrared reflectance spectroscopy. J. Sci. Food Agr. 57:507-515.

Hill, N.S., J.C. Petersen, J.A. Stuedemann, and F.E. Barton II. 1988. Prediction of percentage leaf in stratified canopies of alfalfa with near infrared reflectance spectroscopy. Crop Sci. 28:354-358.

Holechek, J.L., M. Vavra, and R.D. Pieper. 1982. Methods for determining the nutritive quality of range ruminant diets: a review. J. Anim. Sci. 54:363-376.

Moore, K.J., C.A. Roberts, and J.O. Fritz. 1990. Indirect estimation of alfalfa-smooth bromegrass mixtures. Agron. J. 82:287-290.

Norris, K.H., R.F. Barnes, J.E. Moore, and J.S. Shenk. 1976. Predicting forage quality by infrared reflectance spectroscopy. J. Anim. Sci. 43:889-897.

Pitman, W.D., C.K. Piacitelli, G.E. Aiken, and F.E. Barton. 1991. Botanical composition of tropical grass-legume pastures estimated with near infrared reflectance spectroscopy. Agron. J. 83:103-107.

Shaffer, J.A., G.A. Jung, J.S. Shenk, and S.M. Abrams. 1990. Estimation of botanical composition in alfalfa/ryegrass mixtures by near infrared spectroscopy. Agron. J. 82:669-673.

Shenk, J.S., and M.O. Westerhaus. 1991a. Population definition, sample selection, and calibration procedures for near infrared reflectance spectroscopy. Crop Sci. 31:469-474.

Shenk, J.S., and M.O. Westerhaus. 1991b. Population structuring of near infrared spectra and modified partial least squares regression. Crop Sci. 31:1548-1555.

Sparks, D.R., and J.C. Malechek. 1968. Estimating percentage dry weight in diets using a microscope technique. J. Range Manage. $21: 264-265$. 